\title{
Isaiah Berlin and the Origins of the 'Totalitarian' Rousseau
}

\author{
Christopher Brooke \\ University of Cambridge
}

[This is a draft of a chapter that has been accepted for publication by Oxford University Press in the forthcoming book Isaiah Berlin and the Enlightenment edited

by Ritchie Robertson and Laurence Brockliss, due for publication in 2017.]

It is obvious that Isaiah Berlin did not like Jean-Jacques Rousseau, and it is not difficult to think of some possible reasons. But I want to begin this chapter by suggesting that we can choose to be puzzled by this dislike of Rousseau perhaps a bit more than we usually are. Jeremy Waldron elsewhere in this collection discusses Berlin's neglect of what he calls 'Enlightenment constitutionalism', focusing on the ways in which he seemed to lack interest in the hard work of designing a constitutional order in which self-interested, not always virtuous, ambitious men might live together in peace, prosperity, and freedom. Hearing Waldron's paper, I was reminded of Rousseau's attitudes to modern constitutionalism, some of which can be organized under his sarcastic label, 'the masterpiece of policy in our century'. Rousseau - like Berlin — was generally in favour of values such a freedom and equality, but was quite sceptical towards the actually existing constitutionalisms of his own day. Europe was heading into an age of violent revolutions, he thought, and no good would come of them - another point of agreement with Berlin's profoundly antirevolutionary sensibility — and he also thought that the people we might call the progressive intellectuals of his day didn't understand what they were doing with their schemes of social and political improvement, and that this would contribute to their

\footnotetext{
${ }^{1}$ Rousseau, Preface to Narcisse, in Cuvres complètes, Bernard Gagnebin and Marcel Raymond, eds. (Paris, 1964-9), vol. 2, p. 968. For discussion, see Nannerl O. Keohane, "“The Masterpiece of Policy in Our Century": Rousseau on the Morality of the Enlightenment', Political Theory, 6 (1978), 457-84.
} 
likelihood of going badly wrong. ${ }^{2}$ Rousseau, like Berlin, had one foot in the 'CounterEnlightenment', without surrendering entirely to it. Rousseau, like Berlin, described a number of different visions of human freedom and the good life across his various works, from Spartan citizens, to the denizens of Clarens, to solitary walkers. Unusually among Enlightenment intellectuals, perhaps — and the contrast with Voltaire is especially striking here-Rousseau was also not hostile to Judaism. Perhaps Berlin might have warmed to him on that score? Might his sharp antagonism towards Rousseau in part be rooted in what Freud once called the narcissism of small differences?

No. The differences were bigger than that. And the antagonism-well, it was antagonistic. Here are some of the ways Berlin talks about Rousseau. In his radio address of November 1952, Rousseau's tone, he tells us, is 'exactly that... of a maniac...like a mad mathematician' whose 'answer has... a kind of lunacy'. ${ }^{3}$ In the manuscript from the same period that was posthumously published as Political Ideas in the Romantic Age, Berlin repeats his charge three times. Rousseau 'preaches' his argument about the general will, "with the almost lunatic intensity of a somewhat crack-brained visionary'; Rousseau looks for a way of squaring total liberty with total conformity, Berlin says, 'with the fanatical cunning of a maniac'. 'His polemic against the babel of voices all claiming to speak for nature is acute, entertaining and convincing', Berlin writes, 'until one realises that he is like the lunatic who rejects the claims of other inmates of his asylum to be Napoleon because he himself is Napoleon. $^{4}$

In his notes for the Flexner Lectures which Berlin gave at Bryn Mawr earlier the same year, he uses the phrase 'lunatic cunning', 5 and the only other example I can find of his using those words is with reference to Adolf Hitler, in his essay on

\footnotetext{
${ }^{2}$ See, in particular, Béla Kapossy, 'The Sociable Patriot: Isaak Iselin's Protestant Reading of Jean-Jacques Rousseau', History of European Ideas, 27 (2001), 153-70 (pp. 155-8).

${ }^{3}$ FIB 37. I have used the quotations in this paragraph elsewhere, in Christopher Brooke, " "The porch to a collectivism as absolute as the mind of man has ever conceived": Rousseau scholarship in Britain, from the Great War to the Cold War', in Avi Lifschitz (ed.), Engaging with Rousseau (Cambridge: Cambridge University Ptress, forthcoming).

${ }^{4}$ PIRA: 'crack-brained visionary', p. 116; 'cunning of a maniac', p. 112; 'Napoleon', pp. 4647.

${ }^{5}$ MS. Berlin 570, fol. 17.
} 
Winston Churchill that appeared in the Atlantic Monthly in 1949. ${ }^{6}$ And Berlin did associate Rousseau with the Fascist dictators:

Rousseau is the greatest militant lowbrow of history, a kind of guttersnipe of genius, and figures like Carlyle, and to some extent Nietzsche, and certainly D. H. Lawrence and d'Annunzio, as well as révolté, petit bourgeois dictators like Hitler and Mussolini, are his heirs (FB 41).

Rousseau always went along with Carlyle, Nietzsche, and Lawrence in Berlin's mind: they appear together in Political Ideas in the Romantic Age (PIRA 2); in a letter to Violet Bonham Carter in 1954 he talks of the 'old war - since Rousseau - between the civilised and superior and their enemies - not just barbarians, but corrupt \& resentful victims \& casualties of the social system - moral \& emotional cripples of various kinds - sometimes brazen thunderers like Carlyle or D. H. Lawrence or A. J. P. Taylor...' (who is an interesting addition to the demonology) (L II 465). Rousseau, Carlyle, Nietzsche, and Sorel are mentioned in a letter to Richard Wollheim in 1958, where they are also associated with Fascism (L II 611). In a 1972 letter to J. H. Huizinga, he repeats the language of 'thundering': 'I should be as nervous, and indeed, frightened of meeting Rousseau if I had lived in the 18th century, as I should be of Carlyle or Wagner, or D. H. Lawrence or all the other "angry" prophets who thundered at mankind after theological sermons had somewhat gone out of fashion' (L III 512). ${ }^{7}$

Why was Rousseau such a problem for Berlin? Kevin Hilliard points us in the right direction in his contribution to this volume, when he reminds us that the Enlightenment was important for Berlin because he wanted to understand the origins of Marxism, drawing attention to 'moral monism', 'scientism', and 'technocratic mechanism'. Rousseau obviously wasn't either a scientist or a technocratic mechanist in anything like the way in which some of his contemporaries were. But Berlin seems to have become convinced that Rousseau played a key role in the history of this moral

\footnotetext{
${ }^{6}$ Isaiah Berlin, 'Mr. Churchill', Atlantic Monthly, 184, no. 3 (September 1949), 35-44.

${ }^{7}$ It appears that Berlin had been sent, and was commenting on, the typescript of what eventually became J. H. Huizinga, The Making of a Saint: The Tragi-Comedy of JeanJacques Rousseau (London: Hamish Hamilton, 1976).
} 
monism. We know, for example, that Berlin was thinking about Rousseau when he was writing his book about Marx in the 1930s. In a letter to John Hilton from October 1935, Berlin writes:

My summer was peculiar: I am trying desperately to write a book on Marx: \& find myself (a) unable to write at all for at least an hour after settling to, (b) when I begin I suddenly let loose a flood of words about Rousseau's influence on the romantic style, $\&$ then remember that the relevance needs proving. It really is torture: anyhow I spent a month thus, \& then fell ill of the quinsy (L I 137).

Rousseau's influence on the romantic style was the topic to which he returned again and again and again over thirty years, without ever getting his thoughts into a state that he was willing to publish. For the Marx book, he worried here that it was hard to show relevance. The theme recurs in Political Ideas in the Romantic Age, drafted in 1950-2, and, later, there were the 1965 lectures that have been published as The Roots of Romanticism.

Just where is this coming from? Why this early and apparently deep conviction that 'Rousseau's influence on the romantic style' might constitute part of the key for understanding Marxism? That is quite a peculiar thought to have. It looks as if the answer has quite a bit to do with the Russian Marxist Georgi Plekhanov. We know that Berlin was immersed in Plekhanov, for his thinking about Marx in general, and the subject of historical inevitability in particular. And if we turn to Plekhanov's 1895 book on The Development of the Monist View of History, it is striking that there is a discussion of Rousseau in that text, specifically in its fourth chapter, which, interestingly, claims to be a chapter on German idealism. ${ }^{8}$ It is something of a tricky discussion to follow, because Plekhanov is criticising Nikolay Mikhailovsky, who was disagreeing with Frederick Engels, who was writing about Rousseau in his AntiDühring, so there are several layers of commentary in play. One question that was being chewed over in this discussion is whether Rousseau is, properly speaking, a dialectician; but more substantively, there was the question of progress, and

\footnotetext{
${ }^{8}$ G. Plekhanov, The Development of the Monist View of History (Moscow: Progress Publishers, 1956).
} 
Rousseau's relationship to narratives of progress in the context of his account of the contradictions of human social development and civilisation. It is my view that Berlin's distinctive approach to Rousseau developed in the 1930s in part out of this encounter with Plekhanov, and that this framework for worrying about Rousseau remained with him for the rest of his life. This is a view that sits comfortably with the broader scholarship on Berlin. As his biographer Michael Ignatieff has written,

Having fluent Russian gave him a route to Marx barred to most other English scholars, with the exception of E. H. Carr. Russian sources, especially Plekhanov, on the precursors of Marx led him to the Enlightenment thinkers; and from there forward to the nineteenth-century socialists. The reading he did between 1933 and 1938 provided Berlin with the intellectual capital on which he was to depend for the rest of his life. ${ }^{9}$

If that is, as I suspect, the origin of Berlin's own problem of Jean-Jacques Rousseau, what else shaped the way he approached that problem? The first obvious answer is philosophical anti-idealism. Plekhanov, as just noted, had treated Rousseau in a discussion of German idealism, with which Rousseau had also been associated by the older philosophical generation against whom Berlin and an only slightly older generation were reacting so sharply. The reason all these discussions of Rousseau include references to 'true selves' and 'real wills' - the reason why the Rousseau we encounter from these writers is always a proto-Hegelian Rousseau, rather than a recognisably eighteenth-century Rousseau — is because these twentieth-century discussions are so very heavily mediated by late nineteenth-century philosophical idealism - the ideas of Bernard Bosanquet, in particular, but also those of T. H. Green. These were the political philosophers who had been so heavily criticised from the time of the First World War. We shouldn't exaggerate the contribution of L. T. Hobhouse's Metaphysical Theory of the State from 1918. That work is not so much an attack on philosophical idealism in general, as a book by a left-leaning idealist attacking the right-leaning versions of the theory. ${ }^{10}$ (His subsequent books, after all,

\footnotetext{
${ }^{9}$ Michael Ignatieff, Isaiah Berlin: A Life (London: Chatto \& Windus, 1998), p. 71.

${ }^{10}$ L. T. Hobhouse, The Metaphysical Theory of the State: A Criticism (London: G. Allen \& Unwin, 1918).
} 
included both The Rational Good and The Elements of Social Justice. ${ }^{11}$ ) But in Berlin's undergraduate Oxford, as Joshua L. Cherniss has pointed out, H. A. Prichard lectured on T. H. Green on political obligation in 1930 (and we know that Berlin attended those lectures), and E. F. Carritt lectured specifically on 'the general will' in 1932 (though we don't know whether Berlin attended those). ${ }^{12}$

The anti-idealist pendulum continued to swing during the 1930s and 1940s. 'It is fashionable nowadays to discredit the theory of the general will, and an attempt to rehabilitate it is not likely to receive much sympathy', wrote B. Mayo, in a short article on the general will published in the 1950 volume of Philosophy. ${ }^{13}$ And it is perhaps significant in this context that the better books that were being published on Rousseau in the 1930s were by more historically-minded scholars-Alfred Cobban and John Stephenson Spink ${ }^{14}$ — and not by the philosophers, who were losing their interest. The chief exponent of philosophical idealism in the British universities was Michael Oakeshott, but he never had much to say about Rousseau, ${ }^{15}$ and the political theorist who was most interested in working more constructively with the categories of Rousseau's political thought was G. D. H. Cole, who produced the Everyman edition of The Social Contract that is still widely used today, but it is fair to say that what appears to have been Cole's ambition to synthesise aspects of Rousseau's political theory of the general will with his own vision of guild socialism never really came off. ${ }^{16}$

One consequence of the fact that it was the generation who taught Berlin which was most directly concerned with the counter-offensive against philosophical idealism was that Berlin never seems to have felt that he really had to engage with

\footnotetext{
${ }^{11}$ L. T. Hobhouse, The Rational Good: A Study in the Logic of Practice (London: G. Allen \& Unwin, 1921); The Elements of Social Justice (London: G. Allen \& Unwin, 1922).

${ }^{12}$ Joshua L. Cherniss, A Mind and its Time: the development of Isaiah Berlin's political thought (Oxford: Oxford University Press, 2013), p. 156, p. 161.

${ }^{13}$ B. Mayo, 'Is there a Case for the General Will?', Philosophy, 25 (1950), 247-52, reprinted in Peter Laslett, ed., Philosophy, Politics and Society, first series (Oxford: Blackwell, 1956), pp. $92-7$.

${ }^{4}$ Alfred Cobban, Rousseau and the Modern State (London: George Allen \& Unwin, 1934). John Stephenson Spink, Jean-Jacques Rousseau et Genève (Paris: Boivin, 1934).

${ }^{15}$ For what he did have to say, see Brooke, "“The porch to a collectivism...".

${ }^{16}$ For Cole on Rousseau, see Peter Lamb, 'G. D. H. Cole on the General Will: A Socialist Reflects on Rousseau', European Journal of Political Theory, 4 (2005), 283-300. For remarks on Berlin and Cole's Rousseau, see Cherniss, A Mind and its Time, pp. 161-2.
} 
Rousseau as a serious theorist. What I mean by this is that Berlin never writes about Rousseau as if he had encountered a reasonably well-worked out body of psychological, moral, social, and political theory, had noticed various problems with it, and had then tried to construct more adequate theories in their place. I can't think of any passage in Berlin where he treats any of Rousseau's theoretical arguments especially patiently, or seriously. Certainly_and notoriously_Berlin's occasional invocations of Rousseau's deliberately paradoxical formulation about being 'forced to be free' have literally nothing to do with the argument that Rousseau was actually making when he deployed those words. Berlin instead latches onto the phrase, and then uses it to illuminate a more general attitude that he thinks he finds in Rousseau's political thought.

In addition to Plekhanov, and anti-idealism, the next source that structured and shaped Berlin's encounter with Rousseau was the American literary critic, Irving Babbitt, especially his 1919 book, Rousseau and Romanticism. ${ }^{17}$ Indeed, Berlin was interested in Babbitt well before he was working on his Marx book. For example, Babbitt's influence is apparent — and Babbitt is cited directly — in an article, 'Some Procrustations', that appeared in the May 1930 issue of the Oxford Outlook, a periodical with which the young Berlin was involved. ${ }^{18}$ I don't know exactly when Berlin first read Babbitt's Rousseau book, but my hunch is that it was earlier rather than later. If the distinctive problem with which he was wrestling from the mid 1930s was Rousseau's influence on romantic style, for example, it makes sense that he was already reading, by then, the major twentieth century work that addresses exactly this subject. And Babbitt's book clearly had an impact on Berlin. If you look at the marked-up typescript of what was eventually published as Political Ideas in the Romantic Age, for example, one feature that is striking is the almost complete lack of footnotes - perhaps not surprising, for a text that was substantially dictated. The notes in the book that was published from the manuscript have overwhelmingly been supplied by its editor, Henry Hardy. But when Berlin discusses Rousseau, there, in the

\footnotetext{
${ }^{17}$ Irving Babbitt, Rousseau and Romanticism (Boston, Mass: Houghton Mifflin, 1919).

${ }^{18}$ Isaiah Berlin, 'Some Procrustations', Oxford Outlook, vol. X, no. 52 (May 1930), p. 493. The reference is to Babbitt's 'introduction to M. Julien Benda's admirable Belphégor' and Berlin remarks that 'The case against emotionalism is there overstated, but though the method is violent it is nowhere unscrupulous...' Thanks to Joshua L. Cherniss for the reference.
} 
typescript, is one of the very few footnotes indeed, and it's a reference to Babbitt's book. $^{19}$

Babbitt was obviously very critical of Rousseau, and Berlin took over a big chunk of that critical agenda - but it seems to me that the combination of antiidealism and Babbitt created a problem for Berlin that he never quite worked out how to resolve, which partially in turn explains the way in which he returned to scratch the Rousseau-and-romanticism itch over a period of thirty years without ever getting it quite right. The problem relates to the two quite opposed versions of Rousseau that we find here. For the late nineteenth-century philosophical idealists, as much as for their early twentieth-century critics, Rousseau is a proto-Hegelian, an arch-rationalist. For Babbitt, on the other hand, Rousseau is the man of feeling, sentiment, emotion, and imagination. It's practically impossible to synthesize these two approaches to Rousseau, and I'm not sure Berlin was ever able to do so. For the argument about 'positive' freedom that Berlin wanted to prosecute, he required a starkly rationalist Rousseau, but the single book on Rousseau to which he appears to have been most powerfully drawn presented a very different kind of Rousseau indeed. This tension could have been resolved simply by choosing one interpretation of Rousseau over the other. But Berlin couldn't manage to do this, and I suspect that the reason owes to the connection that he forged in his mind between Rousseau and Marxism. It was Marx who, in Berlin's view, had forged a powerful synthesis between the traditions of Enlightenment and Romanticism. Rousseau was interesting to him as a precursor of Marx precisely because these two streams seemed to come together somehow in his writings, too. But without being able to come to a coherent all-things-considered view of Rousseau, he was left at something of an impasse.

The final major influence on Berlin's thinking about Rousseau was Jacob Talmon, whom Berlin met after the Second World War. But before turning to Talmon, I shall say something first about Harold Laski, who plays what seems to me to be a curious role in this story of Berlin's reception of Rousseau. Arie Dubnov has suggested - though without much direct evidence - that one of the stimuli that made made Berlin want to write on Marx was dislike of the way in which Laski wrote on

${ }^{19}$ MS. Berlin 570, fol 154, which is numbered p. 93 of the PIRA MS. 
the subject. ${ }^{20}$ But when we turn to Rousseau, three things catch the eye. The first is that Berlin more or less takes over Laski's approach to Rousseau in his 1930 book, Liberty in the Modern State. ${ }^{21}$ In contrast to Hobhouse's earlier Metaphysical Theory of the State, this book really does make a starkly anti-idealist political argument, in which Laski argues that what is wrong with theories like Rousseau's is the way in which they crowd out space for dissidence. The idealist theory, wrote Laski, 'contradicts all the major facts of experience'; it is 'a denial of that uniqueness of individuality'. 'For as I encounter the state, it is for me a body of men issuing orders'. Laski insists that there must be a space for respecting what Rawls will later call conscientious refusal, a space that he thinks idealism must deny. 'A true theory of liberty, I urge, is built upon a denial of each of the assumptions of idealism...'. What Laski presents there, in fact, looks quite a lot like Berlin's famous subsequent account of negative liberty. ${ }^{22}$

The second connection comes via Talmon himself. Laski had supervised Talmon's doctoral dissertation at the London School of Economics on 'The doctrine of poverty' in the Middle Ages, ${ }^{23}$ and he gets a mention in the acknowledgements to The Origins of Totalitarian Democracy. But the relationship was not always a smooth one. In a letter to Berlin, Talmon confessed to complex thoughts about Laski, on being asked to write for a Hebrew periodical: 'I am somewhat embarrassed: I would have to say some very harsh things about that most ambiguous figure, while the man did his best to earn my gratitude. ${ }^{24}$ And Talmon's own book reverses Laski's own argument at a critical moment. There's a 1930 Laski pamphlet on 'The Socialist Tradition in the French Revolution', which appears in Talmon's bibliography, and the narrative Laski offers there is broadly similar to that which Talmon presents in The Origins of Totalitarian Democracy, except that when Laski gets excited, because things are getting properly socialist in the manner of which he approves, these are exactly the moments - culminating of course in the examination of 'Gracchus'

\footnotetext{
${ }^{20}$ See Arie Dubnov, Isaiah Berlin: The Journey of a Jewish Liberal (Basingstoke: Palgrave Macmillan, 2012), p. 129.

${ }^{21}$ Harold J. Laski, Liberty in the Modern State (London: Faber \& Faber, 1930).

${ }^{22}$ Ibid., pp. 24-6.

${ }^{23}$ J. L. Talmon (writing as J. L. Flajszer), 'The doctrine of poverty in its religious, social and political aspects as illustrated by some XII-XIII century movements', unpublished $\mathrm{PhD}$ (London School of Economics, 1943).

${ }^{24}$ MS. Berlin 286, fol. 6 .
} 
Babeuf - where Talmon locates the full-blown emergence of the messianic model of politics which he presents as the fountainhead of modern despotism. ${ }^{25}$

Laski is also interesting, furthermore, in light of his own relationship to Babbitt's work. He was not only the most prominent public figure in England to be both interested in and critical of Babbitt, but in another curiously Berlin-themed moment, he connected Babbitt's conservative stance to Joseph de Maistre's image of the public executioner, which Berlin would later do so much to popularise, in his 1948 book on The American Democracy. ${ }^{26}$ (While I'm exploring these kinds of links, I can add that Babbitt's most important follower in England was T. S. Eliot, who wrote to Berlin in November 1952 to say how much he enjoyed his Rousseau radio broadcast, and would he be willing to see the radio talks published by Faber \& Faber? ${ }^{27}$ )

And so, to Jacob Talmon and the post-war scene. Before Talmon, Robert Nisbet had been the most prominent scholar to make a sustained argument for a 'totalitarian' interpretation of Rousseau's political thought, ${ }^{28}$ and there had also of course been Bertrand Russell's casual remark in his 1945 History of Western Philosophy that 'Hitler is an outcome of Rousseau; Roosevelt and Churchill, of Locke'. ${ }^{29}$ Before Talmon, there had been other scholars, too, who had floated a distinctive notion of 'totalitarian democracy', such as Bertrand de Jouvenel and E. H. Carr. ${ }^{30}$ But Talmon commands attention not only because he placed Rousseau at the centre of his story about totalitarian democracy, but also because of his closeness to Isaiah Berlin. The two men appear to have met in 1947, and, as Berlin recalled, they were 'discussing what afterwards became the central theme of his most famous book,

\footnotetext{
${ }^{25}$ Harold J. Laski, The Socialist Tradition in the French Revolution (London: The Fabian Society, 1930).

${ }^{26}$ Harold J. Laski, The American Democracy: A Commentary and an Interpretation (New York: Viking Press, 1948), p. 424.

${ }^{27}$ Letter to Berlin from T. S. Eliot, 6 November 1952, MS. Berlin 131, fol. 33.

${ }^{28}$ Robert A. Nisbet, 'Rousseau and Totalitarianism', Journal of Politics, 5 (1943), 93-114.

${ }^{29}$ Bertrand Russell, History of Western Philosophy and its connection with political and social circumstances from the earliest times to the present day (New York: Simon and Schuster, 1945), p. 685.

${ }^{30}$ See Cherniss, A Mind and its Time, p. 172.
} 
Totalitarian Democracy, and since my ideas were tending in the same direction, I found that talking with him was highly stimulating and intellectually delightful., ${ }^{31}$

Talmon's 'most famous book', The Origins of Totalitarian Democracy, was published in 1952, and this year also marks the high tide of Berlin's own dealings with Rousseau. Early in the year he had been in Pennsylvania in order to deliver the Flexner Lectures on 'The Rise of Modern Political Ideas in the Romantic Age'. That year, he is also thought to have completed his draft—never published in his own lifetime — of the related book, Political Ideas in the Romantic Age. In the Autumn, he delivered his famous radio talks on 'Freedom and its Betrayal', the second of which was devoted to Rousseau and was first broadcast on 5 November. Those radio talks in turn prompted a leader column in The Times, written by T. E. Utley, which gave rise in turn to a flurry of correspondence on the letters page, to which Berlin contributed, and on the penultimate day of the year, 30 December 1952, Berlin wrote three letters which bear on my topic, and with which I shall conclude.

The Times leader had juxtaposed the 'rationalist philosophy' of, for example, Rousseau with the 'empirical liberalism' of Mill, and had praised the latter. 'The search for a single sovereign principle, for an all-embracing ideology, has been the bane of the modern world.' But Utley departed from Berlin's line of reasoning when he observed that

Rationalist philosophy has been able to do the harm which it has done because it satisfied an undeniable human need - the need for the faith that history has a purpose and that politics is subject to a consistent moral law. In the past, that faith was supplied - as it can be still-by a Christian interpretation of history... ${ }^{32}$

The correspondence that followed began with a letter from Emile Cammaerts endorsing Utley's pro-Christian conclusion- 'Christianity... appears to-day as the

\footnotetext{
${ }^{31}$ See, e.g., Graeme Garrard, Counter-Enlightenments (London: Routledge, 2006), p. 87. Isaiah Berlin, 'A Tribute to My Friend', Forum, no. 38 (summer 1980), 1-4. Cherniss, A Mind and its Time, pp. 171-2, and especially p. 174 for discussion of the question of mutual influence.

32 'The Fate of Liberty', The Times, 6 December 1952, p. 7.
} 
best means of checking the impatience of those who, while denying the existence of evil, do not hesitate to foster hatred and use brutal force in order to achieve their own end ${ }^{33}$ — but it was the third letter, from Edgar W. Jones, which directly took issue with Berlin's interpretation of Rousseau. Jones had remarked that 'the general will is only the name for that modification which each person must make in his own real will when he seeks to take into account the real wills of other people', and that, 'If this is so, Rousseau is really a good democrat after all...' Berlin, he complained (sensibly enough, in my own view) was trying 'to compress eighteenth-century thinking into a kind of Hegelian strait-jacket which does violence to important parts of its anatomy' ${ }^{34}$ Berlin's own contribution to the correspondence was a somewhat snotty reply to Jones (L II 343-4), who in turn wrote in again to complain that Berlin had 'grossly misrepresented what I wrote'. 35

Turn, finally, to the three letters of 30 December. The first is a letter to a former student, Denis Paul, in which Berlin discusses his radio talks and restates his general ideas about freedom (L II 352-3). The second is a letter to Herbert Elliston, in which Berlin registers his disagreement with aspects of Utley's leader, and also discusses Talmon. 'I have much respect for Talmon's book', he wrote, 'but I think it erroneous in one or two ways, although in general constructed along very much the right lines, ${ }^{36}$ Finally, there is a letter to Talmon himself, which contains a long passage on Rousseau that is of greatest interest for present purposes, and worth reproducing in full:

God knows, the awful shadow of Marx broods over the entire thing, and I do not know whether to put him in or keep him out, and I still feel terribly obscure and muddled about Rousseau. You and I think that he is the father of Totalitarianism in a sense. Why do we think this? Because of the despotism of the general will. What does he, in fact, say? He talks about, (a) the necessity to keep out selfish and sectional interests, so that each man shall ask himself what is it right to do from the point of view of the community in general; this

\footnotetext{
${ }^{33}$ Emile Cammaerts, Letter to the Editor, The Times, 9 December 1952, p. 9.

${ }^{34}$ Edgar W. Jones, Letter to the Editor, The Times, 12 December 1952, p. 9.

${ }^{35}$ Edgar W. Jones, Letter to the Editor, The Times, 18 December 1952, p. 7.

${ }^{36}$ MS. Berlin 131, fol. 301. As Cherniss points out, however, in A Mind and its Time, p.

$173 n$., Berlin does not indicate what those 'one or two ways' might be.
} 
assumes that there is such a thing as a general interest or some course of action which are better for entire societies than others, and this, although none too clear, obviously is in some sense valid; so far so good. One may raise questions about how one ever knows which course is best and then one may reasonably answer that Rousseau's recommendations about eliminating selfish and sectional interests, as practical tips, have a certain value, at least in some situations, and that the difference between what is traditionally considered to be the right frame of mind for members of the English Parliament as against, say, American Senators, who quite openly represent territorial or economic interests, is a case in point. Again so far so good. Furthermore, everyone in the Assembly has the right to express his view as he pleases. Any suppression automatically breaks the social contract and destroys the general will, the Sovereign, etc., so that liberty seems to be guaranteed. But once the decision has been reached the dissidence must form and this, I suppose, is the ordinary practice of all democratic assemblies, from Quaker meetings to Lenin's Regional Central Committee and Politbureau. What then do we complain of? Simply, (a) that Rousseau thinks that an absolutely objectively true answer can be reached about political questions; that there is a guaranteed method of doing so; that his method is the right one; and that to act against such a truth is to be wrong, at worst mad, and therefore properly to be ignored, and that all these propositions are false? (b) the mystique of the soi commun and the organic metaphor which runs away with him and leads to mythology, whether of the State, the Church, or whatever. Is this all? or is there more to complain of? I don't feel sure. The muddle is so great. The precise transition from absolute freedom to absolute necessity is still not very clear to me - it is in Hegel but not in myself. I suppose I must read him again, but if you have thoughts I wish you would tell me. (L II 354-5)

The letter that Talmon said that he would write to Berlin about Rousseau does not appear amongst the Berlin papers, and perhaps it does not exist. ${ }^{37}$ And although Berlin says 'I suppose I must read him again', I am not sure that he ever made real further progress with Rousseau — though we do know, from the testimony of John

\footnotetext{
${ }^{37}$ MS. Berlin 286, fol. 3.
} 
Rawls, that Rousseau was covered in the class he taught with Stuart Hampshire the following term in Oxford, at the start of $1953 .^{38}$ 'Now I must sit down to the hideous task of writing a book', Berlin also wrote in that same letter to Talmon.

But the hideous task, of course, was never completed.

\footnotetext{
${ }^{38}$ Thomas Pogge, John Rawls: His Life and Theory of Justice (New York: Oxford University Press, 2007), p. 16: 'Rawls was especially impressed with a seminar taught by Berlin and Hampshire, with Hart's active participation, in the winter of 1953. This covered Condorcet, Rousseau's Social Contract, John Stuart Mill's “On Liberty,” Alexander Herzen, G. E. Moore, and two essays by John Maynard Keynes.' Berlin was impressed by Rawls: 'There is of course an American here better than all these I should think called Rawls...' Letter to Morton White, 4 March 1953, L II 364.
} 